\title{
Governing EU Health Law and Policy - On Governance and Legislative Politics
}

Martinsen, Dorte Sindbjerg

Published in:

Research Handbook in EU Health Law and Policy

Publication date:

2017

Document version

Peer reviewed version

Citation for published version (APA):

Martinsen, D. S. (2017). Governing EU Health Law and Policy - On Governance and Legislative Politics. In T. Hervey, C. A. Young, \& L. E. Bishop (Eds.), Research Handbook in EU Health Law and Policy (pp. 36-60). Edward Elgar Publishing. 


\title{
Governing EU Health Law and Policy - On Governance and Legislative Politics
}

\author{
Dorte Sindbjerg Martinsen ${ }^{1}$ \\ Published in "Research Handbook in EU Health Law and Policy" Tamara Hervey; Calum Alasdair Young; \\ Louise E. Bishop (eds.).
}

Edward Elgar Publishing, 2017, pp. 36-60.

A European health community was launched as a political idea in the formative years of European integration. Already back in 1952, the French minister of health, Paul Ribeyre presented a detailed idea, with 330 articles of supranational healthcare regulation. ${ }^{2}$ The idea of a European health Community was, however, refused by the Community founding fathers. Health regulation was to be a national prerogative.

Although politics back then could not support a European health community as such, it from early on granted migrant workers access to cross border healthcare as part of the regulation coordinating social security. As early as 1958, the Council of Ministers adopted regulation no. $3^{3}$, according to which migrant workers' could access healthcare in a hosting member state - among other forms of social security. The overall political vision was that the worker was one production factor which together with goods, services and capital should circulate freely across borders. Worker mobility would then again require national barriers to be removed, and access to a hosting member state's welfare system was crucial in this regard. Originally, a European health law and policy therefore emerged as a support function for the common market, firmly justified and tied into the overall idea of free movement of workers. Beyond assisting the common market, member states have resisted the transfer of health policy competences from the national to the supranational level and have insisted on maintaining national control with cross border healthcare. This has resulted in a fine masked system of certain supranational healthcare entitlements, governed through different degrees of national control. In the historical evolvement of European health law and

\footnotetext{
${ }^{1}$ Professor at Department of Political Science, University of Copenhagen. E-mail: dm@ifs.ku.dk. ORCID 0000-00022113-0950. I would like to thank the editors as well as the participants at the workshop 'European Union Health Law and Policy: the state of the art and direction of travel' in Brussels, January 2016, in particular Bart Vanhercke as discussant. The usual disclaimer applies.

${ }^{2}$ C. Parsons (2003) A Certain Idea of Europe, New York: Cornell University Press; 86 ff; H. Vollaard, H. Van de Bovenkamp, H., \& D.S. Martinsen (2016). The making of a European healthcare union: a federalist perspective. Journal of European Public Policy, 23:2: 157-176

${ }^{3}$ Regulation no 3/58 was later revised into regulation $1408 / 71$, which today is regulation $883 / 2004$, which covering not only workers and self-employed individuals but also all EU citizens and their family members.
} 
policy, member states have jealously guarded any expansion of supranational competence. Nevertheless, EU's role in health law and policy has expanded silently, but gradually. ${ }^{4}$

European health policy regulation is based on both primary and secondary law. Important Treaty amendments have taken place over the decades. Originally, article 51 of the EEC Treaty (now article 48 TFEU) laid down that workers can access the social security schemes of a hosting member state. In 1987, the Single European Act introduced a new article, article 118A (article 153(1) a TFEU). This granted the Community the ability to adopt measures to regulate health and safety at work. For the regulation of healthcare, this led to the adoption of the working time directive 93/104, which regulates the maximum hourly work week for healthcare personnel. The Maastricht Treaty introduced a separate article 152 (now article 168 TFEU) on public health. Hereby, the European Union has its own independent Treaty basis for the regulation of health. At the same time, the article emphasize the delicacy in supranational versus national competences in the regulation of health. 168 (5) states that 'any harmonisation of the laws and regulations of the Member States' is excluded and the last part 168 (7) that 'Union action shall respect the responsibilities of the Member States for the definition of their health policy and for the organisation and delivery of health services and medical care'. Finally, while the Amsterdam Treaty did not revise the EU's healthcare commitments as such, the charter of fundamental rights was written into the constitution with the Lisbon Treaty. Article 35 of the charter states that 'Everyone has the right of access to preventive health care and the right to benefit from medical treatment under the conditions established by national laws and practices'.

The Treaty background mirrors the limited political commitment to a fully fletched Union health policy. Nevertheless, a patchy one has involved with key pieces of secondary legislation adopted. The healthcare rights of migrant workers and later person is coordinated by means of Regulation 1408/71, now Regulation 883/2004. As a concrete result hereof, many European citizens now bring along their European health card when travelling. In 1993, the working time directive was decided, regulating an important part of healthcare professionals' working conditions. Also in 1993 the directive on medical devices was adopted. In 1999, the Tobacco directive was adopted and in 2011, the patients' rights directive was agreed upon between the Council and the European Parliament. Especially since the 1990s the European Union has thus come to address major issues of human health and healthcare, including cancer and BSE, tobacco, pollution, working time, pharmaceuticals, and medical devices as well as the free movement of health

\footnotetext{
${ }^{4}$ A. de Ruijter (2015) 'A silent revolution: the expansion of EU Power in the field of human health. A rights-based analysis of EU health law and policy', Doctoral thesis, University of Amsterdam.
} 
professionals, services, goods and patients. ${ }^{5}$ Although clear political commitment and vision for a European health policy lacks, the Union has expanded its regulatory role considerably and in this process, politics has played a role. Political voice may not have sounded loud with vision of a European healthcare Union, but nevertheless EU legislative politics has played a role in setting the scope and limits of EU involvement. Although often disregarded in the scholarly debate, legislative politics in part explains why the regulatory field has evolved into its state of regulation of today.

The remains of this chapter sets out the governing institutions of Union health policy, pointing to the competences and procedures of the European Commission, the Council, the European Parliament, agencies and networks in supranational regulation. The chapter then turns to analyse a concrete process of EU law and legislative politics, namely as it formed in case of the patients' rights directive. The patients rights' directive is the major piece of EU healthcare regulation in recent times, adopted on basis of the Lisbon Treaty and co-legislated by the Council and the Parliament. The legislative process thus demonstrates the attempts of EU actors and institutions to compromise when setting the scope and limits of Union competences. As a case, it furthermore brings forth the political conflict lines of European healthcare regulation which tends to be disregarded in the scholarly debate. Finally, as shown in the conclusion of this chapter, the patient rights directive demonstrates how the output of legislative politics conditions the subsequent outcomes of EU regulation - in this case being patient mobility under the directive.

\section{The Political Institutions of Union Health Governance}

The Court of Justice of the European Union (CJEU) has often been pointed to as a major driver of healthcare integration. It has undoubtedly been a major force in the narration of European health law ${ }^{6}$, extended the definition of what constitute working time ${ }^{7}$ and laid down that the Treaty provisions on free movement of services and goods also applies to healthcare ${ }^{8}$, and thus initiated the dynamics that later resulted in the

\footnotetext{
${ }^{5}$ M. Steffen, W. Lamping. and J. Lehto. (2005) 'Introduction. The Europeanization of health policies', in M. Steffen (ed.), Health Governance in Europe. Issues, challenges and theories, London: Routledge, pp. 1-18; T. Hervey and J. McHale (2015) European Union Health Law: Themes and Implications, Cambridge: Cambridge University Press; D. S. Martinsen (2015) An Ever More Powerful Court? The Political Constraints of Legal Integration in the European Union, Oxford: Oxford University Press; Vollaard et. al (n 2).

${ }^{6}$ T. Hervey (2016) 'Telling stories about European Union Health Law: The emergence of a new field of law'. Comparative European Politics.

${ }^{7}$ Nowak, T. (2008) 'The Working Time Directive and the European Court of Justice'. Maastricht Journal of European and Comparative Law 15(4):447-71; Martinsen (n 5).

${ }^{8}$ S. L. Greer (2006) 'Uninvited Europeanization: neofunctionalism and the EU in health policy'. Journal of European Public Policy 13(1):134-52; D. S. Martinsen (2005) 'Towards an internal health market with the European Court'. West
} 
patient rights directive. However, without political support such legally driven dynamics is likely to produce little change. Both at the supranational and the national level, the way politics have made usages and have responded to these legal dynamics conditions its impact. It matters how and which part of the Commission takes legal integration forth and into political processes. It also matters how and why the Council and European Parliament respond in subsequent legislative processes, and which competences they grant agencies and committees to produce European standards and monitor national implementation practices. Therefore to understand and explain the development of Union health law and policy it is necessary to analyse its governing institutions; the European Commission, the Council of the European Union ${ }^{9}$, the European Parliament as well as health agencies and networks.

The European Commission has the competence to propose Union legislation. In thus has a legislative function and formally initiates the policy process. However, the Commission is by no means a unitary actor but has its internal power conflicts in setting the policies for Europe. ${ }^{10}$ Which part of the Commission proposes and executes health policies is important. Up to 1997, the Commission did not have a specific Directorate General (DG) dealing with health. Instead healthcare was spread across different DGs and Commissioners, with a certain bias towards the internal market. Because of the BSE crisis, the DG for Food and Health safety (SANCO) was formed in 1997 and health thus became an independent portfolio under the Commission. However, DG SANCO has been characterized as politically weak ${ }^{11}$ in comparison with other parts of the Commission. Nevertheless, it has gained increasing competences within the regulation of health as for example demonstrated when it took over the drafting of the patients' rights directive from the DG MARKT (Internal Market). As will be further detailed below, SANCO became lead DG after the European Parliament voted to negotiate cross-border healthcare as part of the service directive. ${ }^{12}$

European Politics 28(5):1035-56; G. Davies (2007) 'The effect of mrs Watts' trip to France on the national health service'. King's Law Journal 18(1):158-67.

${ }^{9}$ Previously the Council of Ministers.

${ }^{10}$ M. Hartlapp, J. Metz and C. Rauh (2014) Which Policy for Europe?: Power and Conflict inside the European Commission, Oxford: Oxford University Press.

${ }^{11}$ S. L. Greer (2009) The changing world of European health lobbies: Oxford: Oxford University Press; A. De Ruijter (2016) 'The Institutional Consolidation of EU Human Health Expertise'. Comparative European Politics.

${ }^{12}$ De Ruijter (n 4, 234-235). Martinsen (n 5, 148-149). 
In the ordinary legislative procedure for EU decision-making, the Council of the European Union and the European Parliament act as co-legislators. For the regulation of health policies, the national ministers meet in the EPSCO Council (Employment, Social Policy, Health and Consumer Affairs Council). Before the ministers decide, positions and compromises have been prepared in the relevant Council working group, where civil servants from the national health ministries and the national permanent representations meet on a more regular basis. If a common Council position is within reach or if conflicts cannot be solved between working group members, the dossier will be discussed by the Council's Committee of Permanent representatives, COREPER, where the ambassadors from the permanent representations sit. Council decision-making thus have decisive preparatory committees, where healthcare experts from the national ministries meet with their counterparts on a regular basis. These forums are found to be important sites for arguing and bargaining and thus for gradually forming the compromise, establishing the common position between member states. ${ }^{13}$ Also the rotating Council presidency is important in this regard. ${ }^{14}$ The civil servants representing the presidency will chair the negotiations in the working group and conduct informal talks and bilateral negotiations with his counterparts when need be.

The European Parliament (EP) has increased its powers as co-legislator, also in the field of health policy. However, its institutional impact on health legislation is rather unexplored. To have influence on the adopted policies, the intra-institutional dynamics within the parliament as well as its inter-institutional relation with the Council and the Commission are important for the EP. Intra-institutional dynamics will be conditioned by the EP political majority but also by which political group holds rapporteurship on a dossier as well as the internal dynamics in the EP committee preparing the file. In health, the EP Committee on Environment, Public Health, and Food Safety (ENVI) will typically be responsible for the dossier. It will, however, also have to consider proposed amendments from other relevant committees in its final report. For health, the EP committee on Employment and Social Affairs (EMPL) and the committee for the Internal Market (IMCO) are of particular relevance. In the ordinary legislative procedure, the decision-making process will be that when the Commission has come forward with its proposal, the proposal is referred to

\footnotetext{
13 J. Beyers and G. Dierickx (1998) 'The working groups of the Council of the European Union: supranational or intergovernmental negotiations?'. JCMS: Journal of Common Market Studies 36(3):289-317; D. Naurin (2010) 'Most common when least important: deliberation in the European Union Council of Ministers'. British Journal of Political Science 40(01):31-50.

${ }^{14}$ Tallberg, J. (2003) 'The agenda-shaping powers of the EU Council Presidency'. Journal of European public policy 10(1):1-19; Warntjen, A. (2007) 'Steering the Union. The Impact of the EU Presidency on Legislative Activity in the Council'. JCMS: Journal of Common Market Studies 45(5):1135-57.
} 
the responsible EP committee and often to one or more committees for their opinion. ${ }^{15}$ The next step is then to nominate a rapporteur within the committee. It is the rapporteur's task to prepare discussions on the dossier in the committee, to present a draft report and to amend it on the basis of the observations of committee members. The committee will then vote on the final report of the rapporteur. Subsequently the rapporteur will present the report to the EP plenary and its vote will be cast. The rapporteur will also be the primary negotiator with the Council presidency to establish an inter-institutional compromise and finally have the legislative text adopted. The position and parliamentary capacity of the rapporteur is therefore highly important. Rapportuership is prestigious, especially on the more important dossiers. Committees chose rapporteurs on the basis of a system of points. Each political group has a quota of points according to their size and they can then opt for proposals where they would like rapportuership on. Thus the larger groups therefore gets rapportuership on the more important proposals, typically making their bids here. The political groups not getting the rapportuership will nominate shadowrapportuers who will then negotiate with the rapportuer. The shadowrapportuers from the larger political groups will all take part in negotiations with the Council and the European Commissions, in the so-called trialogues.

Such trialogues will be formed for the inter-institutional negotiations between the Council, the European Parliament and the Commission. Representatives from the different institutions will engage here in trying to establish a common agreement. The ordinary legislative procedure can involve three negotiations rounds, first, second and third reading. First reading agreements have become the established law-making norm in the EU today with the large majority of proposals concluded at this stage. ${ }^{16}$ Despite a considerable different set of positions and interests in the Union, inter and intra-institutional dynamics of formal and informal arguing and bargaining, working groups and committees, rapporteurs, shadowrapportuers and presidency are the actors and sites of action which enables consensus-building in EU legislative politics.

Apart from legislative politics, agencies and network are important sites for European healthcare governance. Out of the 40 decentralised and executive Union agencies, 5 deals with health related policies $^{17}$; the European Agency for Safety and Health at Work, the European Centre for Disease Prevention and Control, the European Monitoring Centre for Drugs and Drug Addiction, the European Medicines

\footnotetext{
${ }^{15}$ For the intra-institutional EP dynamics, see C. Richard, J. Francis and S. Michael (2007) 'The European Parliament'. Londra, John Harper 20118, 135-145.

${ }^{16}$ D. Judge and D. Earnshaw (2011) 'Relais actors' and co-decision first reading agreements in the European Parliament: the case of the advanced therapies regulation'. Journal of European Public Policy 18(1):53-71; M.D. Jensen and D. Martinsen (2015) 'Out of Time? National Parliaments and Early Decision-Making in the European Union'. Government and Opposition 50(02):240-70.

${ }^{17}$ See http://europa.eu/about-eu/agencies/index en.htm for list of Union agencies.
} 
Agency and the Consumers, Health, Agriculture and Food Agency. In comparison, the European Medicines Agency (EMA) enjoys the most considerable regulatory competence as it is responsible for the scientific evaluation and approval of applications for the authorisation of medical products. Pharmaceutical companies must submit a single authorisation application to the EMA and once granted, the authorisation is valid in all EU member states as well as in the European Economic Area (EEA) countries. Most of the agency evaluation work is carried out by its seven scientific committees ${ }^{18}$, which consists of health authorities from the EEA countries. The committees are instrumental to the development, assessment and supervision of medicines in the Union. Furthermore, the agency brings together a European regulatory network of national competent authorities in the European Medicines Network.

In general the literature on European agencies and regulatory networks concludes that agencies and network have regulatory impact in developing standards and are able to promote harmonized rules at the domestic level. ${ }^{19}$ It is also found that although European agencies and networks are decentralized units, their work is shadowed by the Commission. The Commission plays an active role in networks and agencies, using these as a back road to informal harmonization of regulatory practices as well as solving compliance problems. ${ }^{20}$ However, when considering the impact of European health agencies and networks for the integration of national health policies and law, findings are more mixed. It is found that despite decades of EU regulation and the considerable mandate of the EMA, a single European market for pharmaceuticals and medical devices has faced substantial obstacles. ${ }^{21}$ The impact of the EMA suffers from the constitutional asymmetry of European healthcare integration, where EU free movement principles clash with member states' insisting to preserve national healthcare competences. In addition, EU regulation of pharmaceuticals as well as medical devices are found to suffer an industrial bias, where the medicine

\footnotetext{
${ }^{18}$ By $1^{\text {st }}$ January 2016, the seven scientific committees counted the Committee for Medicinal Products for Human Use (CHMP), the Pharmacovigilance Risk Assessment Committee (PRAC), the Committee for Medicinal Products for Veterinary Use (CVMP), the Committee for Orphan Medicinal Products (COMP), the Committee on Herbal Medicinal Products (HMPC), the Committee for Advanced Therapies (CAT) and the Paediatric Committee (PDCO).

${ }^{19}$ B. Eberlein and A. L. Newman (2008) 'Escaping the international governance dilemma? Incorporated transgovernmental networks in the European Union'. Governance 21(1):25-52; M. Maggetti (2007) 'De facto independence after delegation: A fuzzy-set analysis'. Regulation \& Governance 1(4):271-94; M. Maggetti (2014) 'The politics of network governance in Europe: the case of energy regulation'. West European Politics 37(3):497-514.

${ }^{20}$ M. Martens (2008) 'Administrative integration through the back door? The role and influence of the European Commission in transgovernmental networks within the environmental policy field'. European Integration 30(5):63551; M. Hobolth and D. S. Martinsen, D. (2013) 'Transgovernmental networks in the European Union: Improving compliance effectively?'. Journal of European Public Policy 20(10):1406-24.
}

${ }^{21}$ C. Altenstetter and G. Permanand (2007) 'EU Regulation of medical devices and pharmaceuticals in comparative perspective'. Review of policy research 24(5):385-405; G. Permanand and Mossialos, E. (2005) 'Constitutional asymmetry and pharmaceutical policy-making in the European Union'. Journal of European Public Policy 12(4):687709. 
industry has been more successful in influencing the technical harmonization than patients' organisations and interests. EU regulation hereof is found to lack policy advocacy. ${ }^{22}$

Together, these institutions form the governing structure for the health policies of the European Union. In the subsequent sections, the legislative politics behind the adoption of the patient rights directive in 2011 will be examined. Furthermore it will be demonstrated how the output of legislative politics condition subsequent outcomes, i.e. implementation results.

\section{Legislating the EU Patients' Rights Directive ${ }^{23}$}

The importance of EU legislative politics appears to be somewhat neglected in the study of EU health governance. The literature has mainly emphasised the importance of EU law and the CJEU, or examined the role of the Commission in EU health regulation. However, extending EU competences into health policy and law is a process ripe with political conflicts, as the negotiations of the patients' rights directive demonstrate. In this process, four institutions; the CJEU, the Commission, the Council and the EP, and a wide array of actors took center stage.

\section{Agenda-setting patients' rights in cross-border healthcare}

The right to access healthcare in another member state was adopted between the original member states as one of the first Community regulations which granted migrant workers the right to have their social security rights, including healthcare, coordinated across borders. From first on, it was politically adopted to achieve the aims of a common market, albeit in the politically setting of the original six member states. Concerning healthcare, member states maintained considerable control of patients seeking planned health treatment in another member state. According to regulation 1408/71 and later 883/2004 such had to be authorized beforehand from the competent institution of the migrant, typically the home member state. the competent authority's discretionary scope to grant or refuse cross-border healthcare was considerable indeed and de facto by most member states seldom granted. ${ }^{24}$ The prior authorization policy of secondary legislation thus affirmed the territoriality of health policy and law.

\footnotetext{
${ }^{22}$ Altenstetter and Permanand (n 21). Permanand and Mossialos (n 21).

${ }^{23}$ This part draws on the empirics from Martinsen 2015 (n 5, 133-185). The empirical material consist of official and official documents concerning the negotiations of a patient rights' directive as well as a large set of interviews with key respondents, involved in the decision-making process of the directive.

${ }^{24}$ E. Mossialos, M. McKee and W. Palm (2002) 'EU Law and the Social Character of Health Care', in. Brussels: Peter Lang, 85; D. S. Martinsen (2007) 'EU for the patients: Developments, impacts, challenges'. Swedish Institute for European Policy Studies (SIEPS) 6:1-60, 14.
} 
However, the justifiability of territoriality was challenged by the line of CJEU judicial interpretations where the Court ${ }^{25}$ laid down that also the principles of free movement of goods and services applied to the field of healthcare. Jurisprudence was thus an important push for further health policy integration, challenging national control. The interesting question becomes if legislative politics had the capacity and willingness to respond to this legal push for integration?

The first political reactions to the CJEU jurisprudence were harsh, finding that the Court had taken it too far. First a Treaty amendment was called for. ${ }^{26}$ When that was deemed impossible, the member states called for the Commission to re-establish legal certainty.

The Commission first responded to this call by 'deafening silence'. ${ }^{27}$ DG MARKT was then assigned responsibility and in March 2004 proposed cross border health regulated as part of the service directive, proposing to codify the case-law of the Court. ${ }^{28}$ Member states expressed their fierce opposition, refusing to have the health area regulated as part of a general directive on services under the responsibility of DG MARKT. ${ }^{29}$ However, it became the EP to veto this part of the service directive and the Commission was send back to the drafting table. The dossier changed hands, and DG SANCO became responsible for drafting a new proposal. SANCO was now in charge and when it finally presented its proposal in July $2008^{30}$, it had adapted to some of the national concerns. Non-hospital care should still circulate freely, but for those non-

\footnotetext{
${ }^{25}$ See in particular the following cases; C-120/95 Decker [1998] ECR I-01831; C-158/96 Kohll [1998] ECR I-01931; C368/98 Vanbraekel [2001] ECR I-5363; C-157/99 Geraets-Smits and Peerbooms [2001] ECR I-05473; C-326/00 Ioannidis [2003] ECR I-1703; C-385/99 Müller-Fauré and Van Riet [2003] ECR I-04509; C-56/01 Inizan [2003] ECR I12403; C-8/02 Leichtle [2004] ECR I-2641; C-372/04 Watts [2006] ECR I-4325; C-466/04 Acereda Herrera [2006] ECR I5431; C-444/05 Stamatelaki, [2007], ECR I-3185; C-211/08 Commission v Spain [2010] ECR I-5267; C-512/08 Commission v France [2010] ECR I-8857; C-490/09 Commission v Luxembourg [2011] ECR I-249; C-255/09 Commission v Portuguese Republic [2011] ECR I-10547; C-173/09 Elchinov [2010] ECR I-8889.

${ }^{26}$ D.S. Martinsen and G. Falkner (2011) 'Social Policy: Problem-Solving Gaps, Partial Exits, and Court-Decision Traps', in G. Falkner (ed.), The EU's Decision Traps. Comparing Policies. Oxford: Oxford University Press, pp. 128-45.

${ }^{27}$ W. Palm, J. Nickless, H. Lewalle and A. Coheur (2000) 'Implications of recent jurisprudence on the co-ordination of health care protection systems', in. Bruxelles: AIM: Association Internationale de la Mutualite, pp. 1-170, 78.

${ }^{28}$ Proposal for a Directive of the European Parliament and of the Council on services in the internal market, COM (2004) 2, 3 March 2004, article 23.

${ }^{29}$ R. Baeten and W. Palm (2013) 'The Compatibility of Health Care Capacity Planning Policies with EU Internal Market Rules', in J.W. van de Gronden, E. Szyszczak, U. Neergaard and M. Krajewski (eds.), Health Care and EU Law. The Hague: T.M.C. Asser Press, pp. 389-413, 390.

${ }^{30}$ Proposal for a Directive of the European Parliament and of the Council on the application of patient rights in crossborder healthcare, COM (2008) 414.
} 
hospital treatments defined as highly specialized and cost-intensive, PA would be justifiable as well as PA could be used for hospital care. However, hospital care, highly specialized and cost-intensive care should rely on a Community definition. ${ }^{31}$ If member states could not provide treatment without 'undue delay', they would be obliged to authorize cross-border healthcare.

Although SANCO had hereby extended the use of PA, it at the same time restrained its use. Highly specialized and cost-intensive care should be included on a specific list, under the control of the Commission and regulated by the Comitology procedure. Furthermore, member states should prove that PA was necessary by providing evidence that outflow of patients would 'seriously undermine or [was] likely to seriously undermine' the financial balance, planning, or rationalization of the hospital sector. ${ }^{32}$ The member states' burden of proof when using the PA procedure was thus considerable. ${ }^{33}$

With this modification of the previous Commission position, negotiations on the proposal initiated in the EP and the Council.

\section{Political negotiations in the European Parliament}

During political negotiations, positions in the EP and the Council were split on especially two conflict lines. An ideological conflict dimension between left and right along which different positions on equality emerged. Political actors disagreed on how much the directive should aim to ensure equality in patients' ability to use cross-border healthcare. In addition, a conflict dimension on more versus less European integration was vivid throughout negotiations. Political actors and the Commission disagreed on the scope conditions of internal market principles versus the justifiability of national control with the provision of healthcare services, i.e. more integration versus subsidiarity.

In order to establish the necessary majority in the EP, a compromise had to be reached between the three largest political groups; the conservative European People's Party (EPP), the liberals (ALDE) and the Socialists and Democrats (S\&D). ENVI became the responsible EP committee on the proposal and rapportuership was assigned to the EPP group. EPP nominated the British MEP Johan Bowis to carry out the task. Both the EPP and ALDE largely favored the Commission's proposal from the start. However, for ALDE it

\footnotetext{
${ }^{31}$ As set out in article 8.2 of COM (2008) 414.

${ }^{32} \operatorname{COM}(2008) 414,14$, recital 31, and article 8.3.b.

${ }^{33}$ L. Hancher and W. Sauter (2012) 'EU Competition and Internal Market Law in the Health Care Sector', Oxford: Oxford University Press, 206-207; Martinsen (n 5, 153).
} 
was important to work for the greatest possible equality in patients' ability to exercise their cross-border rights. ALDE therefore proposed a European patient ombudsman to which patients could complain. Furthermore, ALDE had preferred a stronger application of free movement principles than the Commission proposed. On the other hand, the S\&D political group were much more critical towards the dossier. In addition, the group disagreed internally on the proposal. The German MEP Dagmar Roth-Behrendt became the S\&D shadowrapportuer on the file, and her individual position was more in favour of the proposal than the S\&D 'back-benchers'. The common position of the group became that the Treaty basis of the proposal had to be changed into also including TFEU 168 and not only be based on the internal market provision 114 TFEU. Furthermore, S\&D worked for more national autonomy on when to grant prior authorization. ${ }^{34}$

The first reading of the proposal took place six months before the 2009 EP election. In the heat of elections, MEPs appeared less willing to compromise and it was difficult for the rapporteur to establish a compromise between the different positions. No less than 1600 amendments were submitted to the proposal, but the final Bowis rapport had managed to merge them into 100. A total of 115 amendments were adopted during the first reading. The adopted EP amendments would imply more national control by extending the scope of when the prior authorisation procedure could be used for which type of care. Furthermore, the EP majority position aimed to strengthen patients' rights and ensure equality. A new article had been adopted which would allow patients with rare diseases to go for cross-border care without prior authorization (article 8.9). Concerning equality, the EP added a voucher system according to which a patient could receive a voucher from their competent state authorizing cross-border care and certifying that the treatment would be paid by them (article 10). This provision aimed to enhance equal rights, independent of means:

"When we say the policy should be about patients with needs, not patients with means, we should make it clear we do not wish to see patients having to travel, clutching cash or credit card to pay upfront for often expensive in-hospital treatment. We should put in place a system of reimbursement direct from home funder to receiving hospital, either through a Central Clearing House to manage the cross-border, crosscurrency, cross-system (Beveridge/Bismarck) complications, or by a bi-lateral voucher system for the patient to take to the hospital and guaranteeing the latter payment by the Member State of Affiliation". ${ }^{35}$

Finally, the EP inserted a new article 11, which would establish a European patient ombudsman, whose tasks would be to deal with patients' complaints on prior authorization, reimbursement, or harm.

\footnotetext{
${ }^{34}$ Martinsen (n 5, 158-159).

${ }^{35}$ Draft report PE 415.355 (Rapporteur: John Bowis), 20 November 2008, 31.
} 
Despite a formal common position, the EP was de facto much divided on the issues. Political disagreements were still many, as mirrored in the votes cast. The proposal was only approved by a narrow simple majority; 297 MEPs voted in favour, 120 voted against and 152 abstained from voting. Most S\&D members abstained from voting and some voted against.

Although the EP had established a narrow majority, it had not done so in time to reach a first reading agreement with the Council. In June 2009, a new European Parliament was elected and the new EP was cast into a second reading of the proposal. As the former rapporteur John Bowis had not run for the new parliament, rapportuership was taken over by EPP member Françoise Grossetête, whereas Dagmar RothBehrendt continued as S\&D shadow rapporteur. During the EP second reading, the scope of PA continued to be the main issue. ALDE and EPP members were critical of extending PA authorization, but S\&D members wanted more national control with cross-border care and therefore supported the Council's position on extended national control. Against this background, the EP rapporteur, together with the shadow rapporteurs from S\&D and ALDE, was ready to start trialogue negotiations with the Council presidency and the Commission.

\section{Political Negotiations in the Council}

The Council working group kicked of negotiations by being indeed internally divided, and with only two or three member states supporting the Commission's proposal. For the first year, the positions were largely divided into three groups. Sweden and Belgium supported the proposal. A second group of more reluctant member states, which were, however, willing to negotiate, counted the UK, the Netherlands, France, Germany and Denmark among others. Finally a large third group of Southern and Eastern European Council members opposed the dossier and found it a wronged intervention in national competences. The different positions seemed indeed informed by the degree to which CJEU case-law had been implemented in the respective member states. ${ }^{36}$

The list of member states' concerns was long. The majority of member states were against the Commission's proposal of a Community definitions of 'hospital care', 'highly specialized and cost-intensive care', which according to the proposal should be put on a Community list, controlled and regularly updated by the Commission. The opposing member states argued that this would not allow them sufficient control, and in fact endanger the sustainability and steering capacity of national healthcare systems. Many member

\footnotetext{
${ }^{36}$ Martinsen (n 5, 164-166).
} 
states also voiced concerns about inflow of patients and the obligation to treat them equally with national patients. How to deal with inflow of patients was not addressed in the Commission's proposal, except that patients from other member states should enjoy equal treatment. Furthermore, a number of member states wanted to extend the legal basis of the proposal to also include 168 TFEU. In addition, concerns were raised about the general practioner (GP) as gate-keeper if patients could consult a GP in another member state and here through be referred for further treatment. Also many member states were against to have to reimburse healthcare, which was provided by a non-contracted provider in another member state. The position was that this would be indirect discrimination as those seeking cross-border healthcare would be able to access treatment by a non-contracted, i.e. a private, provider whereas those staying home would not. This group of member state argued that the directive should be similar to Regulation $883 / 2004$, which only allowed for treatment by providers contracted by the member state of treatment.

During negotiations in the Council, the rotating presidencies formulated compromise texts. SANCO took part in working group negotiations as well as in bilateral meetings with the presidencies and individual member states. However, the Commission found that negotiations were taking a wrong turn, in particular when it came to the national focus on extending the use of the PA procedure. As here noted by the Czech presidency, the Commission found that such extension would be against the case-law of the Court:

"The Commission has a general reserve on the entire Presidency compromise text. In particular it has major concerns with regard to the approach on quality and safety as provided for in Article 5; the approach on prior authorisation which in the Commission's view does not reflect the case law, including the definition of care that can be subject to prior authorisation, which has been significantly broadened" (Czech presidency progress report, 3 June 2009, 2008/0142(COD), 5).

In December 2009, the Swedish presidency presented a compromise text for a Council common position. Among other changes to the Commission's proposal, it contained a dual legal basis, broadened the use of the PA procedure and abolished the article 8.2 of the proposal. However, a Spanish led blocking minority, which also included Poland, Romania, Portugal, Greece, Ireland, Hungary, Slovakia, Slovenia, and Lithuania vetoed the Swedish compromise text. Spain wanted a special arrangements for EU citizens, having changed residence to another MS. In more concrete terms, the controversy concerned pensioners from the Northern member states residing at the Southern coasts. According to regulation 883/2004, an EU citizen which change residence to another MS also change to MS of affiliation in healthcare terms. For residing pensioners, the new MS of affiliation takes over responsibility, but is reimbursed a fixed amount from the 
member state of origin. The political concern was that the directive would give residing pensioners from the UK and northern Europe a better opportunity to go back to their MS of origin to be treated there when ill and the new member state of affiliation would have to bear the costs. Furthermore, Spain and Poland also voiced strongly against access to non-contracted providers in other member states, arguing that this would be reverse discrimination for those patients not going for cross border healthcare. ${ }^{37}$ In general, the blocking minority raised concerns about the cost-containment of the proposal.

The veto put the Council in a peculiar position as the lead of the blocking minority, Spain, took over presidency in January 2010 and member states expected negotiations to be halted as a consequence. However, after some meetings with the Commission, the Spanish presidency came forward with a new compromise, which would solve 'the Southern problem'. Spain proposed an article which would share potential costs of pensioners, having taken up residence in a new MS, which then became the MS of affiliation. According to this article, treatments falling under the scope of PA would still be reimbursed by the new MS of affiliation. This would be less risky for a new MS of affiliation, because costs could be contained through the PA as a means of control. For the treatments not requiring PA, the MS of origin would resume the costs if they had carried out the treatments for citizens, now residing in another MS. ${ }^{38}$

With this amendment, the Spanish compromise text was adopted by a qualified majority in the Council. The decision did not follow the usual consensus norm in the Council. Poland, Portugal, Romania and Austria voted against the compromise text. The first three MS in particular due to the inclusion of non-contracted providers, and Austria voted no due to stark opposition from its Länder, which in particular feared inflow of foreign patients. ${ }^{39}$ Finally Slovakia abstained from voting.

Inter-institutional Negotiations on the Patients' Rights Directive

\footnotetext{
${ }^{37}$ M. Kloka and S.K. Schmidt (2015) 'Legislative and Judicial Politics in the Post-Maastricht Era. The Intergovernmentalist Paradox in the Council', in C. Bickerton, D. Hodson and U. Putter (eds.), European Politics in the Post-Maastricht Era. States, Supranational Actors and the New Intergovernmentalism. Oxford: Oxford University Press; H. Nys (2014) 'The Transposition of the Directive on Patients' Rights in Cross-Care Healthcare in National Law by the Member States: Still a Lot of Effort to Be Made and Questions to Be Answered'. European journal of health law 21(1):1-14, 12.

${ }^{38}$ For this special rule, see article 7.2.b of the final directive $2011 / 24$.

${ }^{39}$ Martinsen (n 5, 169-170). T. Kostera, T. (2014) 'When Europa meets Bismarck. Cross-border Healthcare and Usages of Europe in the Austrian Healthcare System'. Bruxelles: Université Libre de Bruxelles. Doctoral Thesis, pp. 1-309, 243269.
} 
Inter-institutional negotiations on the dossier did not start in earnest before autumn 2010, as both the Council and the European Parliament had had their considerable difficulties in establishing an own institutional position. From October to December 2010, the Belgian Council presidency held four formal trialogues and a set of informal ones with the EP rapporteur, shadow rapporteurs and the European Commission. ${ }^{40}$ The major issue was still the scope of prior authorization. Whereas the Council and the EP were now in agreement, the Commission positioned against the compromise established, which it found to go against the case-law of the Court. However, the European legislators gained momentum in this late stage of negotiations when the CJEU on 5. October came out with its ruling on the infringement procedure against France. ${ }^{41}$ As a surprise to the Commission, the Court took a much more 'tempered approach'42, ruling that PA was justified for non-hospital care when major medical equipment was used. The Commission was thus in a weaker position to argue against the extension of the PA.

The EP also had to give in on some of its top priorities, which aimed to ensure equality in cross border healthcare. It had already abandoned the idea of an European patient ombudsman in its second reading. Confronted with the Council common position, it now had to give up on the voucher system as well as a binding provision on cross-border treatments without PA for patients with rare diseases. Instead rare diseases were written into the recitals and article 13, but without binding measures.

On an inter-institutional comparison, the Council stand out as the winning part, coming through with most of its concerns. As proposed by the Commission, member states would only have to reimburse up to what a similar treatment cost in the member state of affiliation and only for treatments provided by the healthcare package of the MS of affiliation. Furthermore, as evidenced in articles 4-8, the adopted version of the directive had enhanced the steering capacity of the national health authorities much when compared to the Commission's proposal. ${ }^{43}$ The PA procedure was enhanced and member states would set out what defines as hospital, highly specialized and cost-intensive care. They would still have to grant authorization when treatment could not be provided without undue delay. However, the directive did not contain any Community definition of 'undue delay' which remains a very open concepts left to member state

\footnotetext{
${ }^{40}$ Martinsen (n 5, 173 ff.).

${ }^{41}$ C-512/08 European Commission v French Republic [France] [2010] ECR I-8833.

${ }^{42}$ V. Hatzopoulos and T. Hervey (2013) 'Coming into line: the EU's Court softens on cross-border health care'. Health Economics, Policy and Law 8(01):1-5.

${ }^{43}$ Baeten and Palm (n 29, 410).
} 
clarification. Also the burden of proof that member states would have to carry when using PA had been relaxed. ${ }^{44}$ Thus, concerning the outflow of patients, MS had re-established considerable national control. Moreover, the inflow of patients was now also considered in a binding provision of the directive. The Council had insisted that member states of treatment could derogate from the principle of equal treatment if need be, and a new safeguard measure had been adopted by means of article 4.3, allowing member states the possibility 'to fence off their healthcare markets' ${ }^{45}$

As table 1 demonstrates that legislative politics downscaled key provisions of the original Commission proposal and significantly modified the implications of what the Court had initiated. The output of legislative politics became a much paled version of an internal healthcare market, with considerable more national control and territoriality reinserted.

Table 1: The Output of Legislative Politics

\begin{tabular}{|c|c|c|}
\hline & $\begin{array}{l}\text { Commission proposal COM (2004) } 414 \\
\text { as of } 2 \text { July } 2008\end{array}$ & $\begin{array}{l}\text { Directive 2011/24/EU - Patients' Rights } \\
\text { Directive in Cross-Border Healthcare }\end{array}$ \\
\hline Legal basis & $\begin{array}{l}\text { Proposed as article } 95 \text { of the Treaty (now } \\
\text { article } 114 \text { TFEU). }\end{array}$ & $\begin{array}{l}\text { Article } 114 \text { TFEU and } 168 \text { TFEU of the } \\
\text { Treaty }\end{array}$ \\
\hline & $\begin{array}{l}\text { Article 7: Non-hospital care shall not be } \\
\text { subject to prior authorization } \\
\text { Article 8: } \\
\text { Prior authorisation justifiable for hospital } \\
\text { care, highly specialized and cost- } \\
\text { intensive care included on a specific list } \\
\text { What qualifies as highly specialized and } \\
\text { cost-intensive shall be controlled by the } \\
\text { Commission } \\
\text { PA is justifiable provided that MS prove }\end{array}$ & $\begin{array}{l}\text { Article 7: Non-hospital care shall not be } \\
\text { subject to prior authorization } \\
\text { Article 8: } \\
\text { Prior authorisation is justified for 'highly } \\
\text { specialized and cost-intensive' healthcare } \\
\text { as well as for hospital care } \\
\text { Member states defines what constitutes } \\
\text { 'highly specialized and cost-intensive care' } \\
\text { PA has to be limited to what is necessary } \\
\text { and proportionate }\end{array}$ \\
\hline
\end{tabular}

\footnotetext{
${ }^{44}$ Hancher and Sauter (n 33, 207).

${ }^{45}$ Hancher and Sauter (n 33, 208).
} 


\begin{tabular}{|c|c|c|}
\hline & $\begin{array}{l}\text { the outflow of patients is 'seriously } \\
\text { undermining' or likely to 'seriously } \\
\text { undermine' the financial balance of the } \\
\text { social security system, its planning, or } \\
\text { rationalization } \\
\text { Authorisation shall be granted when } \\
\text { treatment cannot be provided without } \\
\text { undue delay }\end{array}$ & $\begin{array}{l}\text { Authorisation shall be granted when } \\
\text { treatment cannot be provided without } \\
\text { undue delay }\end{array}$ \\
\hline Incoming patients & $\begin{array}{l}\text { Patients from other MS shall enjoy equal } \\
\text { treatment }\end{array}$ & $\begin{array}{l}\text { MS of treatment may depart from the } \\
\text { principle of non-discrimination and adopt } \\
\text { measures for foreign patients access to } \\
\text { treatment in order to 'ensure sufficient } \\
\text { and permanent access to healthcare } \\
\text { within its territory' }\end{array}$ \\
\hline Scope & $\begin{array}{l}\text { Only applies to healthcare which is part } \\
\text { of the healthcare package in the MS of } \\
\text { affiliation }\end{array}$ & $\begin{array}{l}\text { Only applies to healthcare which is part of } \\
\text { the healthcare package in the MS of } \\
\text { affiliation. } \\
\text { Sets out that the directive does not apply } \\
\text { to long-term care or to access to organs }\end{array}$ \\
\hline Providers & $\begin{array}{l}\text { Also non-contracted providers are within } \\
\text { the scope of the directive }\end{array}$ & $\begin{array}{l}\text { Also non-contracted providers are within } \\
\text { the scope of the directive. }\end{array}$ \\
\hline $\begin{array}{l}\text { Reimbursement } \\
\text { level }\end{array}$ & $\begin{array}{l}\text { Up to the level of costs in the MS of } \\
\text { affiliation }\end{array}$ & $\begin{array}{l}\text { Up to the level of costs in the MS of } \\
\text { affiliation }\end{array}$ \\
\hline Payment & Up front payment by the patient & Up front payment of the patient. \\
\hline Rare diseases & No recitals or articles deal herewith & $\begin{array}{l}\text { Recital and article } 13 \text {, but no binding } \\
\text { measures }\end{array}$ \\
\hline
\end{tabular}

\section{Conclusion - How legislative Output Condition Outcomes}

The governing institutions of EU health policy and law consist of a considerable mix of actors and institutions, with different positions and interests on what should be the balance between supranational and national competences in Union healthcare regulation. In the studies of EU healthcare regulation, most 
importance has been assigned to the actions and dynamics of the European Court and the Commission. However, politics should be brought in if we are to understand how legislative outputs are produced and the scope and limits of EU health regulation are set. Outputs which then come to condition the subsequent outcomes of regulation.

The patients' rights directive constitutes the output of EU legislative politics analysed above. The output matters to who benefits from the directive and to what extent. As to the conflict dimensions entailed in the political process, it is clear that the directive does not ensure equality as voiced by political actors to the left. Furthermore extensive national control was achieved, meaning less integration than envisioned by the Commission, few member states, the EPP and ALDE. Majoritarian politics adopted five key provisions, which in essence disincentivize patients from seeking healthcare in another member state:

- The patient can only access treatment which $\mathrm{s} / \mathrm{he}$ is already entitled to at home.

- The patient will be reimbursed only up to the tariff for a similar treatment at home. In particular, patients from member states with low reimbursement levels will be less able to be treated across borders.

- The patient will have to pay up front. Patients with small means will be less able to be treated across borders.

- The system of prior authorization is maintained for hospital care and highly specialized and costintensive care. National control has been extended for the most important public treatments.

- Treatment of foreign patients can be refused for capacity, planning, and financial reasons. The principle of equal treatment does not apply in full but can be derogated from.

The derogations from internal market principles created by legislative politics matter in the subsequent implementation of the directive. The output of legislative politics matters to the extent to which patients will actually use the rules and thus the regulatory outcomes. In order to assess the impact of the directive we have to ask; how many patients have been reimbursed for treatment across borders according to the directive? Studies examining the implementation of the directive and its outcome so far demonstrates limited use of the directive. Studies on Bulgaria ${ }^{46}$, the Czech Republic ${ }^{47}$, Denmark ${ }^{48}$, Latvia ${ }^{49}$, Malta ${ }^{50}$, the $^{2}$

\footnotetext{
${ }^{46} \mathrm{~N}$. Vasev and Vrangbæk (2014) 'Transposition and National-level Resources: Introducing the Cross-Border Healthcare Directive in Eastern Europe', in: West European Politics, pp. 693-710; N. Vasev, K. Vrangbæk and F. Křepelka (2016) 'The End of Eastern Territoriality? CJEU Compliance in the New Member States'. Comparative European Politics.
} 
Netherlands ${ }^{51}$, Poland $^{52}$ and Spain $^{53}$ show that these member states have taken extensive use of the PA procedure to counteract potential patient outflows. The impact of the directive in terms of actual patient mobility is so far found to be negligible as table 2 demonstrate for Bulgaria, Denmark and Spain:

Table 2: Outflow of patients in Denmark, Bulgaria and Spain in accordance with the Patients' Rights Directive in $2014^{54}$

\begin{tabular}{|l|l|l|l|}
\hline & Bulgaria & Denmark & Spain \\
\hline $\begin{array}{l}\text { Reimbursement for } \\
\text { treatments that do not } \\
\text { require prior } \\
\text { authorisation since 1/1- }\end{array}$ & 21 & 3 \\
2014 & & & \\
\hline $\begin{array}{l}\text { Prior authorisation } \\
\text { granted since 1/1-2014 }\end{array}$ & 2 & 14 & \\
\hline
\end{tabular}

${ }^{47}$ Vasev, Vrangbæk and Křepelka (n 46).

${ }^{48}$ H. Vollaard and D. S. Martinsen (2014) 'Bounded Rationality in Transposition Processes: The Case of the European Patients' Rights Directive'. West European Politics 37(4):711-31; D.S. Martinsen and J. Mayoral Diaz-Asensio (2016) 'A Judicialisation of Healthcare Policies in Denmark and Spain? The Universalist Healthcare Model Meets the European Union '. Comparative European Politics.

${ }^{49}$ S. Olsena (2014) 'Implementation of the Patients' Rights in Cross-border Healthcare Directive in Latvia'. European journal of health law 21(1):46-55.

${ }^{50}$ N. Azzopardi-Muscat, C. Aluttis, K. Sorensen, R. Pace and H. Brand (2015) 'The impact of the EU Directive on patients' rights and cross border health care in Malta'. Health Policy 119(10):1285-92.

${ }^{51} \mathrm{H}$. Vollaard (2016) 'Patient mobility, changing territoriality and scale in the EU's internal market'. Comparative European Politics.

${ }^{52}$ Vasev and Vrangbæk (n 46); Vasev, Vrangbæk and Křepelka (n 46).

${ }^{53}$ D.S. Martinsen and Mayoral Diaz-Asensio (n 48).

${ }^{54}$ See D. S. Martinsen and N. Vasev (2015) 'On a Difficult Encounter. National Healthcare Models and the European Union', in: Social Policy and Administration; D.S. Martinsen and Mayoral Diaz-Asensio (n 48). Data for Denmark and Bulgaria covers the period 1/1-2014 to 20/10-2014. Data for Spain covers the period 1/1-2014 to 1/1-2015. 
In September 2015, the Commission came out with its "report on the operation of Directive 2011/24/EU on the application of patients' rights in cross-border healthcare" ${ }^{55}$ The Commission, albeit in rather neutral terms, reports on a difficult transposition process where infringement procedures were launched against 26 member states due to late or incomplete transposition. 21 member states have made use of the PA procedure. In general, patient flows under the Directive are noted as very low. France, Finland and Luxembourg have high figures but the figures reported is a mix of healthcare reimbursed with regulation $883 / 2004$ as legal ground and the directive. It is also interesting that Denmark is noted as the member state with most reimbursement under the directive. However, on closer examination, the large majority of reimbursed treatments concerns dental treatment, which has been a right for patients since 2000 as a result of the Decker and KohII ${ }^{56}$ CJEU jurisprudence. This right is now regulated as part of the Directive. In a response to the Danish parliament, the Danish Healthcare Minster noted that for the 3 regions which were able to give detailed information on cross border healthcare, $98 \%$ of all applications concerned dental care amounting to $78 \%$ of all costs reimbursed for healthcare in another member state as according to the patient rights' directive. ${ }^{57}$

This is not to conclude that the directive has not had or will not have any impact in the member states. In some member states the directive has resulted in health reforms, such as bills of patients' rights and the adoption of healthcare packages..$^{58}$ In other member states, it may put pressure on health authorities to improve the quality and efficiency of national healthcare in order to avoid patients making use of the directive. ${ }^{59}$ This form of indirect impact, however, remains to be seen. So far - as a result of legislative politics - the outcomes of the patients' rights directive have been negligible.

\footnotetext{
${ }^{55} \operatorname{COM}(2015) 421$ final, 4. September 2015

${ }^{56}$ See n 25.

${ }^{57}$ Parliamentary question of the Danish Parliament 752 of 24. April 2015. This info has been cross-checked and confirmed by contact to the Danish national contact point.

${ }^{58}$ M. Kattelus (2014) 'Implementation of the Directive on the Application on Patient's Rights in Cross-border Healthcare (2011/24/eu) in Finland'. European journal of health law 21(1):23-32.Olsena (n 49); Azzopardi-Muscat et. Al. (n 50).

${ }^{59}$ M. Schwebag (2014) 'Implementation of the cross-border care directive in EU Member States: Luxembourg'. European journal of health law 21(1):56-64: Olsena (n 49).
} 